\title{
Circulating nucleic acids in plasma and serum (CNAPS): applications in oncology
}

This article was published in the following Dove Press journal:

OncoTargets and Therapy

6 July 2013

Number of times this article has been viewed

\author{
José A González-Masiá \\ Damián García-Olmo² \\ Dolores C García-Olmo 3 \\ 'General Surgery Service, General \\ University Hospital of Albacete, \\ Albacete, ${ }^{2}$ Department of Surgery, \\ Universidad Autónoma de Madrid \\ and La Paz University Hospital, IdiPaz, \\ Madrid, ${ }^{3}$ Experimental Research Unit, \\ General University Hospital \\ of Albacete, Albacete, Spain
}

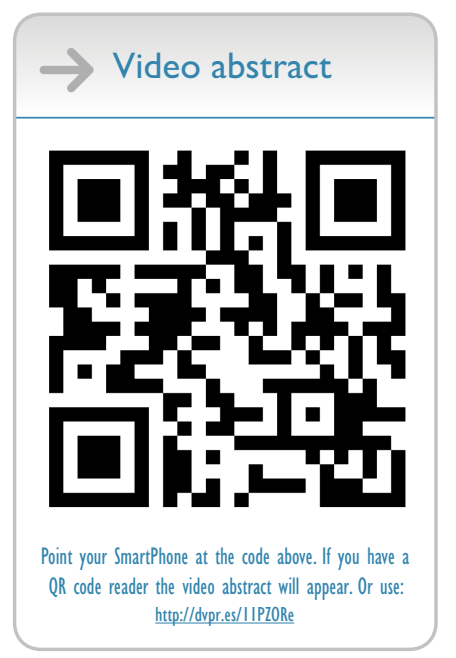

Correspondence: Dolores C GarcíaOlmo

Unidad de Investigación, Hospital General Universitario de Albacete, C/ Hermanos

Falcó 37, 02006 Albacete, Spain

Tel +349675975 I3

Fax +34967243952

Email doloresg@sescam.jccm.es

\begin{abstract}
The presence of small amounts of circulating nucleic acids in plasma and serum (CNAPS) is not a new finding. The verification that such amounts are significantly increased in cancer patients, and that CNAPS might carry a variety of genetic and epigenetic alterations related to cancer development and progression, has aroused great interest in the scientific community in the last decades. Such alterations potentially reflect changes that occur during carcinogenesis, and include DNA mutations, loss of heterozygosity, viral genomic integration, disruption of microRNA, hypermethylation of tumor suppressor genes, and changes in the mitochondrial DNA. These findings have led to many efforts toward the implementation of new clinical biomarkers based on CNAPS analysis. In the present article, we review the main findings related to the utility of CNAPS analysis for early diagnosis, prognosis, and monitoring of cancer, most of which appear promising. However, due to the lack of harmonization of laboratory techniques, the heterogeneity of disease progression, and the small number of recruited patients in most of those studies, there has been a poor translation of basic research into clinical practice. In addition, many aspects remain unknown, such as the release mechanisms of cell-free nucleic acids, their biological function, and the way by which they circulate in the bloodstream. It is therefore expected that in the coming years, an improved understanding of the relationship between CNAPS and the molecular biology of cancer will lead to better diagnosis, management, and treatment.
\end{abstract}

Keywords: plasma, cancer, clinical tool, microRNA, heterozygosity, tumor suppressor genes, viral genomic integration, biomarkers

\section{Introduction}

According to the World Health Organization, cancer mortality will increase by $45 \%$ from 2007 to 2030 due to the demographic increase and population aging. ${ }^{1}$ For that reason, many efforts have been made to find sensitive and specific biomarkers for early diagnosis, prognosis, and management of patients during treatment and follow-up.

A variety of tumors secrete proteins into the bloodstream that are routinely used as tumor markers in clinical practice, such as the prostate-specific antigen in prostate cancer, the alpha-fetoprotein in hepatocarcinoma, the carcinoembryonic antigen (CEA) in colon cancer, the cancer antigen (CA) 15.3 in breast cancer, and the CA19.9 in pancreatobiliary tumors. ${ }^{2}$ However, those techniques might lack sensitivity in nonsecretory tumors, and might give positive results due to inflammatory processes or benign illnesses, limiting their specificity. In addition, there are no known serum markers for most tumors, which highlights the need for extensive study of the biology of tumors to propose new clinical tools. Indeed, it is expected that an improvement in 
the knowledge of the molecular biology of cancer will lead to earlier diagnosis and more effective treatments.

Cancer is produced and progresses as a consequence of complex and gradual processes, in which a variety of genetic and epigenetic alterations are involved (eg, mutations, hypermethylations), and which mainly result in uncontrolled cell growth. Those molecular alterations can be found in the bloodstream, ${ }^{3}$ which suggests that we could find understanding of the molecular biology of a specific cancer in plasma (Figure 1). This was the start point for the study of the so-called cell-free nucleic acids in plasma and serum (CNAPS) as cancer biomarkers.

Although in the last decades the CNAPS concept has generated a considerable interest in the research community, the concept was first suggested many years before this. Specifically, Mandel and Métais ${ }^{4}$ first reported the existence of cellfree DNA (cfDNA) in plasma in the mid-twentieth century. However, their study had scarce impact until 30 years later, when Leon et $\mathrm{al}^{5}$ demonstrated that cancer patients had higher cfDNA levels than normal people and that patients with persistently high levels of cfDNA after treatment had a worse prognosis than those in whom cfDNA levels decreased.

Some years later, Stroun et $\mathrm{al}^{6}$ suggested that at least some of the cfDNA in serum or plasma was derived from the primary tumor, but this hypothesis was only confirmed later by two nearly parallel studies that described the presence of
$K R A S$ mutations in plasma from patients with pancreas neoplasm $^{7}$ and acute myelogenous leukemia. ${ }^{8}$ Those discoveries were the milestones that opened new pathways for cancer biology research and the search for new clinical tools.

The term "CNAPS" refers to different types of cell-free nucleic acids (cfNAs), such as genomic DNA (gDNA), mitochondrial DNA (mitDNA), viral DNA and RNA, messenger (m)RNA, and microRNA (miRNA), which have recently been reported to be present in plasma., ${ }^{3,-13}$

In spite of the increasing number of studies focused on CNAPS, and of the technological improvements, nowadays, some important aspects of CNAPS biology remain unknown, such as their release mechanisms, ${ }^{14}$ method of circulation, ${ }^{15-18}$ and biological role in cancer progression. ${ }^{19}$ Limiting factors in the study of CNAPS have mainly been the lack of harmonization of laboratory techniques, the heterogeneity of the disease progression, and the small number of recruited patients in most of studies, which is for some authors ${ }^{9}$ an example of poor translation of basic research into clinical practice.

\section{Circulating cfDNA Biology of cfDNA}

It has been reported that cfDNA is a double-stranded molecule of low-molecular weight that is fragmented into short (70-200 base pairs) and long sections (up to 21 kilobases). ${ }^{20}$ The analysis of those fragments has deepened understanding

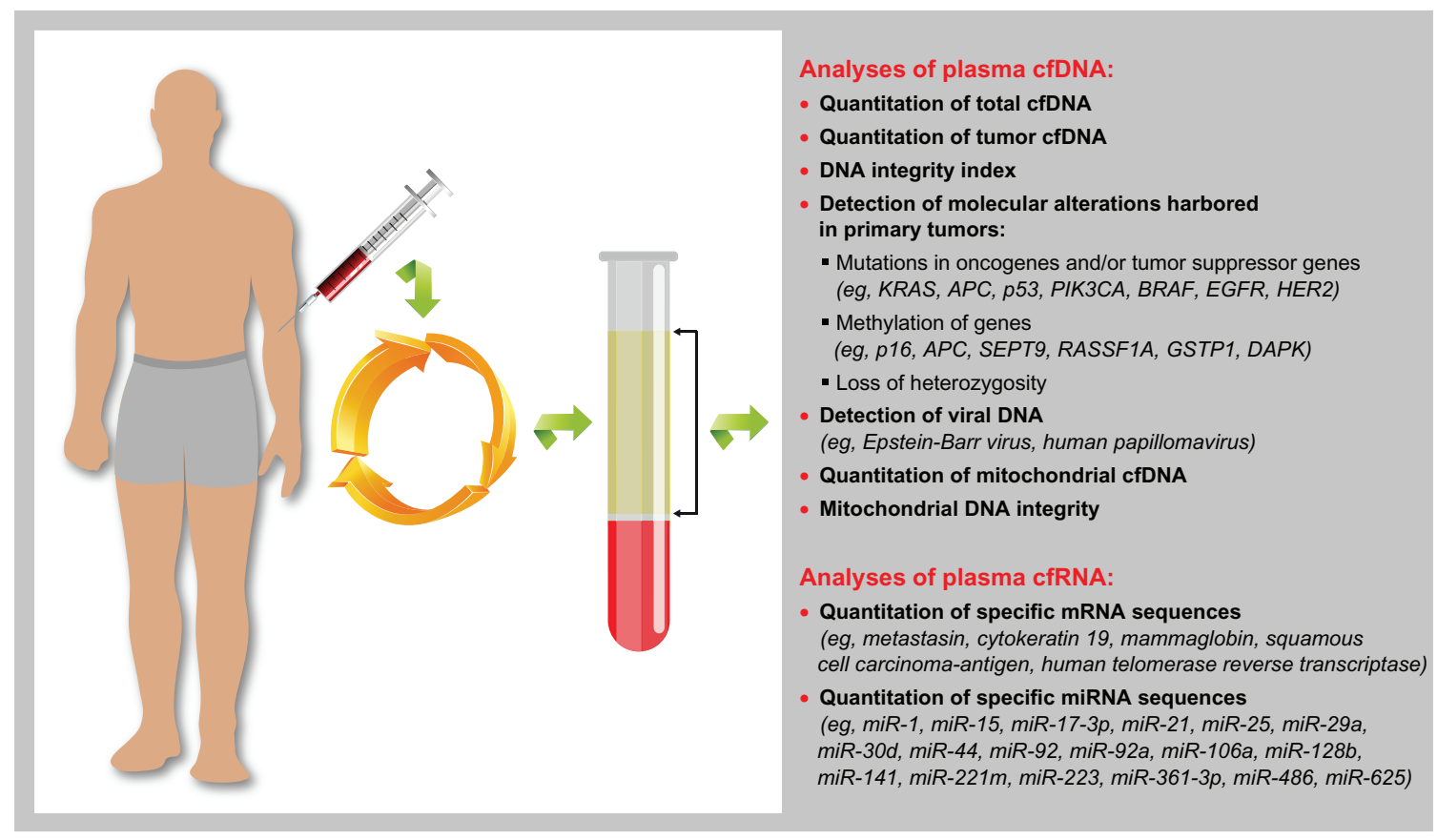

Figure I Graphic representation of the analyses of cell-free nucleic acid (cfNA) circulating in plasma that have been tested in cancer patients and that might serve as clinical markers.

Abbreviations: mRNA, messenger RNA; cfDNA, cell-free DNA; cfRNA, cell-free RNA; miRNA, micro RNA. 
of their origin. ${ }^{21}$ For some researchers, the main source of cfDNA has been necrosis, ${ }^{22,23}$ while others have proposed apoptosis in view of the size of the DNA fragments detected in plasma. ${ }^{20}$ In addition, several studies have suggested the active release of cfDNA by cells, ${ }^{14,24}$ and specifically by lymphocytes. ${ }^{25}$ Therefore, two possible sources of cfDNA, non-mutually exclusive, have been considered: passive release through cell death and active release by cell secretion. Nonetheless, recent studies using genome-wide sequencing of plasma DNA have demonstrated that such DNA contains representation of the entire tumor genome and reflects the clonal genomic evolution of tumors. ${ }^{26}$

Theoretically, CNAPS would be rapidly degraded in the bloodstream by nucleases; it has even been proven that mutated cfDNA degrades faster than non-mutated cfDNA. ${ }^{27,28}$ However, the enzymatic action might be limited because at least part of cfDNA appears to be protected by being complexed or particulate with special protective characteristics against enzymatic degradation. ${ }^{29-31}$ A decreased activity of DNase has also been observed in plasma from cancer patients, which might be another reason for the high levels of cfDNA found in plasma. ${ }^{31}$

\section{Quantitation of cfDNA in plasma and serum}

Many studies have confirmed the early findings of Leon et al. ${ }^{3,9}$ In fact, high concentrations of cfDNA have been reported in plasma and serum from patients with various cancers, such as cancer of the colon, ${ }^{33}$ lung, ${ }^{34-36}$ breast, ${ }^{37,38}$ stomach, ${ }^{39}$ and esophagus. ${ }^{40}$ The clinical value of such quantitation for differential diagnosis was suggested in a large study by Shapiro et al, ${ }^{41}$ who showed that patients with benign gastrointestinal diseases had a lower mean concentration of plasma cfDNA (118 ng/mL) than cancer patients $(412 \mathrm{ng} / \mathrm{mL})$.

Several studies have proposed the use of the quantitation of cfDNA in plasma as a method for screening colon, ${ }^{33}$ breast, ${ }^{38}$ and lung cancers ${ }^{36,42}$ among others. In colon cancer patients, such a method has showed an even better sensitivity than CEA quantitation. ${ }^{33}$ In breast cancer patients, plasma levels of cfDNA have also been related to clinicopathological variables such as size, tumor stage, lymphadenopathies, human epidermal growth factor receptor 2 (HER2)/neu level and state. ${ }^{38}$ In lung cancer, it has even been suggested that the concentration of circulating DNA might be a risk factor for the presence of the illness and a prognostic index during follow-up. ${ }^{36}$

However, in extensive revisions, the use of quantitation of cfDNA in plasma as a unique marker has been questioned ${ }^{9}$ and has even been proposed as inadvisable in lung cancer ${ }^{43}$ and associated with CA125 in ovarian cancer. ${ }^{44}$ In addition, it is remarkable that overlapping concentrations of cfDNA are found in healthy individuals under physiological stress (eg, physical exercise) or in patients affected by other pathological processes, such as, inflammation, trauma, or sepsis. ${ }^{3,45-47}$

The validation of the clinical utility of methods for detection and quantitation of plasma cfDNA has probably failed because of technical limitations, particularly those related to sensitivity and specificity. There have been some attempts to establish reference values for different types of cancer, ${ }^{48}$ however, the lack of harmonization in the laboratory techniques (quantitative polymerase chain reaction [PCR], spectrophotometry, fluorimetry, etc) and the low number and heterogeneity of patients enrolled in each study, have prevented the achievement of suitable statistical power and the establishment of reference patterns. . $^{3,9,10}$

Although, theoretically, the levels of cfDNA in plasma might be affected by several clinicopathological features such as tumor size, tumor stage, or metastasis, ${ }^{9,38}$ no direct relationship between these features has been proven, as Lecomte et al discussed in their review focused on colorectal cancer. ${ }^{49}$ García-Olmo et al have conducted studies in animal models to deepen understanding of cfDNA kinetics and have repeatedly shown that non-mutated DNA levels are not significantly related to tumor size or metastasis. ${ }^{50,51}$ In fact, they found that large amounts of non-tumor DNA are released during tumor progression and, in particular, at the early stages, suggesting that there is active interaction between tumor and non-tumor cells. ${ }^{50}$

It is probable that the quantitation of cfDNA in plasma will be of most clinical value during disease monitoring. ${ }^{42}$ It has been reported that plasma levels decreased in cancer patients after surgical treatments $\mathrm{s}^{33,35,37,39,40}$ and/or chemoradiotherapy, ${ }^{52}$ sometimes reaching levels similar to those measured before treatment. ${ }^{35,39,40}$ In addition, patients who maintained high levels of cfDNA in plasma either did not respond to the treatment or had a high risk of relapse..$^{5,33-37,53}$

Circulating nucleosomes, as degradation products of necrotic tumor cells in the bloodstream, have also been examined and quantified by enzyme-linked immunosorbent assay techniques. ${ }^{16}$ The DNA of necrotic cells, after being phagocytosed by macrophages, ${ }^{23}$ might be released to the bloodstream inside those structures, which protect it from enzymatic degradation. Nucleosomes have been found in healthy subjects and in patients with benign diseases, ${ }^{15}$ thus, their value as a screening method appears to be limited; however, there is some evidence to support their utility 
for cancer monitoring. Specifically, during chemotherapy treatments, an initial increase of the levels of nucleosomes has been observed in plasma, which might be related to apoptosis provoked by treatment, and a later decrease in patients who had a good response to the treatment. ${ }^{15,54,55}$

\section{Molecular alterations of cfDNA}

Most of the molecular alterations found in cfDNA circulating in plasma reflect the genetic and epigenetic changes found in primary tumors and, thus, the analysis of such tumor cfDNA might be valuable for tumor diagnosis and monitoring. Highly sensitive methods are required to detect those alterations among larger quantities of non-altered cfDNA molecules and, for this reason among others, extremely varied results have been reported. ${ }^{3,20,56}$

Following, we review the alterations in cfDNA most frequently found in plasma from cancer patients and tumorbearing animals.

\section{Integrity of the DNA strand}

Using PCR, Wang et $\mathrm{al}^{57}$ found that long DNA fragments, related to necrosis phenomena, could be distinguished from shorter fragments, produced by physiological apoptosis phenomena. These findings gave rise to the so-called integrity index, based on the ratio between long and short cfDNA fragments. The integrity index was established based on gynecologic and breast cancers, ${ }^{57}$ with the results obtained from 61 patients compared with those from 65 patients without neoplastic disease. It was found that the area under the curve for the DNA integrity index was 0.911 in cancer patients in relation to patients without cancer, with $100 \%$ sensitivity and $62 \%$ specificity. The authors suggested that the integrity index provides a simple and inexpensive way to detect cancer. ${ }^{57}$

A number of transposable elements of the genome, such as ALU and LINE1 sequences, can be easily detected and have been associated with tumor necrosis. Specifically, ALU sequences are short elements (typically 300 nucleotides in length) that account for more than $10 \%$ of the human genome. Umetani et al developed a method to measure the integrity of cfDNA in serum using quantitative PCR for ALU repeats, and suggested that the integrity index is increased at the early stages of the disease and a promising molecular biomarker for detecting colorectal and breast cancer. ${ }^{58,59}$ Moreover, it might serve as a sensitive method to detect nodal metastases in the early stages, having an even higher predictive value than the clinicopathological variables commonly used, such as tumor size and stage. ${ }^{59}$
In a recent study in patients with hepatitis B virus-related hepatocellular carcinoma, the integrity index was associated with tumor size, TNM Classification of Malignant Tumors (TMN) stage, and nodal metastasis, and showed a more discriminatory power than total cfDNA concentration. ${ }^{60}$

Further, in other recent studies, the clinical value of the integrity index has been demonstrated, not only for the diagnosis but also the monitoring of the disease. For example, it has been found that the integrity index decreases in parallel to the response to surgical treatments for head and neck tumors $^{61}$ and melanoma, ${ }^{62}$ to chemotherapy in leukemia, ${ }^{63}$ to radiotherapy in nasopharyngeal tumors, ${ }^{64}$ and to chemoradiotherapy in colorectal cancer. ${ }^{52}$ Moreover, it has been reported that patients with high concentrations of integrity DNA had shorter disease-free intervals. ${ }^{64}$

Alterations in the integrity of DNA have also been detected in other organic liquids, such as urine, and can be used in the early diagnosis of bladder cancer without cytology. ${ }^{65}$ Some authors have emphasized that the integrity index meets many of the requirements of a universal biomarker; ${ }^{10}$ however, other studies have not supported this idea. ${ }^{66}$

\section{Gene mutations}

As previously mentioned, many studies have shown that gene mutations found in primary tumors can be also detected in cfDNA circulating in plasma. The literature reports a wide percentage range of patients in whose plasma such mutations have been detected. The differences between studies might be due to technical reasons, since sensitive techniques are needed to detect very small amounts of mutated DNA among larger quantities of un-mutated DNA, which has a dilution effect.

The gene that has most frequently been examined is the KRAS oncogene, which is mutated in variable rates in high-incidence tumors, such as colon, pancreas, lung and thyroid tumors, ${ }^{9}$ and has intrinsic characteristics that make it useful as a marker. ${ }^{49}$ In fact, the prevalence of $K R A S$ mutations is near $50 \%$. Such mutations occur in the early stages of carcinogenesis and are mostly produced at specific sites (particularly in codon 12), which facilitate its detection using PCR-based techniques.

With respect to colorectal cancer, $K R A S$ mutations have been found in $40 \%-50 \%$ of patients, and have also been detected in the plasma or serum of $25 \%-30 \%$ of patients. ${ }^{49}$ Kopreski et al ${ }^{67}$ tried to correlate the detection of KRAS mutations in plasma with clinicopathological findings detected by colonoscopy. They enrolled into their study one of the largest series of colorectal cancer patients that has ever been enrolled into similar studies, and detected $K R A S$ mutations in plasma 
from $83 \%$ of patients whose tumors had such mutations. ${ }^{67}$ Moreover, they also found that some patients with apparently normal colonoscopy had KRAS mutations in plasma, which might be related to the presence of precancer lesions, thus suggesting the technique's suitability for early diagnosis and screening. ${ }^{67}$

In a review by Sorenson, ${ }^{68}$ the author defended the detection of $K R A S$ mutations in plasma as a specific marker for gastrointestinal tumors, with $2.5 \%$ false positives, although the review of studies showed that the concordance with $K R A S$ plasmatic mutations with respect to primary tumor was only $50 \%$. It has also been reported that other mutations, different from those in primary tumors, can be detected in plasma from cancer patients, which might be due to clone heterogeneity in tumors. ${ }^{69}$

In patients with pancreas cancer, it has been shown that detecting $K R A S$ mutations in plasma is useful for early diagnosis as a complementary marker together with other serum markers (eg, CA19.9). ${ }^{70}$ Other researchers have also used it for disease monitoring. ${ }^{71}$

In a prospective study conducted by Gormally et $\mathrm{al}^{72}$ of a healthy population, $K R A S$ mutations were detected in plasma from $1.2 \%$ subjects and p53 mutations in 3.6\%. The authors suggested that $K R A S$ mutations are detectable in plasma before the diagnosis of bladder cancer. In contrast, KRAS mutations have been detected by other researchers in up to $30 \%$ of healthy individuals $;{ }^{9}$ this has been interpreted as a limitation of the diagnosis and screening value.

With respect to mutations in other genes, Chen et $\mathrm{al}^{73}$ used an ultrasensitive technique to detect p53 mutations in plasma from patients with Stage II and III breast cancer, and their results showed a correlation between such detection and the clinical course of the disease after therapy.

The value of detection of tumor mutations in plasma for monitoring the response to treatment has been analyzed in several studies. Diehl et $\mathrm{al}^{74}$ showed that the detection and quantification of mutated cfDNA in plasma from colon cancer patients undergoing surgery and chemotherapy were more useful for monitoring than the quantitation of CEA in serum. In addition, a recent study has shown that the use of panels with the most frequent mutations in colorectal cancer (APC, KRAS, TP53, PIK3CA, and BRAF) was more useful than using CEA and CA19.9 levels. ${ }^{75}$ Further, it has been suggested that, in the postoperative period, the levels of mutated $K R A S$ in plasma are a more powerful predictor of recurrence than Dukes stage. ${ }^{76}$

In breast cancer patients, the presence of amplified HER 2 has been demonstrated in circulating cfDNA during follow-up. ${ }^{77}$ This led the researchers to propose such amplification as a marker for prognosis and response to treatment with monoclonal antibodies, such as trastuzumab. ${ }^{77} \mathrm{~A}$ recent study has provided proof of the concept that tumor cfDNA circulating in plasma represents a highly sensitive biomarker of tumor burden in metastatic breast cancer. ${ }^{78}$ Specifically, the researchers developed new methods to identify somatic genomic alterations (point mutations, structural variants) and designed personalized assays to quantify tumor cfDNA circulating in plasma from 30 patients. They found that levels of tumor cfDNA showed a greater dynamic range and greater correlation with changes in tumor burden than did CA15-3 or circulating tumor cells. ${ }^{78}$

Many chemotherapeutic agents act on pathways in which $K R A S, B R A F, E G F R$, or $p 53$ are involved. ${ }^{79,80}$ For this reason, in many cases, it is important to know the mutation status for predicting the response to treatment and monitoring the disease. The analysis of plasma offers a noninvasive and quick way to find out this information and, in this sense, it has been reported that detection of EGFR mutations in plasma might be useful to predict disease progression, disease-free intervals, and drug resistances in patients with lung cancer. ${ }^{79-81}$ Moreover, it has recently been reported that sequencing of cancer exomes in serial plasma samples might be useful to track genomic evolution of metastatic cancers in response to therapy. ${ }^{26}$ The researchers described a noninvasive approach for characterizing cancer exomes in plasma that might enable detailed and comprehensive evaluation of clonal genomic evolution associated with treatment response and resistance. ${ }^{26}$

Summarizing, patients whose tumors have specific mutations might be monitored by analyzing the tumor cfDNA in their plasma samples. ${ }^{10,26,78}$

\section{Gene hypermethylations}

Some tumors are related to specific epigenetic alterations (eg, methylation), leading to changes in the expression of promoters of suppressor genes, which results in their silencing. Such alterations occur early in tumorigenesis and in DNA fragments that are rich in cytosine and guanine (CpG islands). The first observations were reported in 1999 by Esteller et al ${ }^{82}$ in non-small cell lung carcinoma; now, the detection of these alterations represents one of the most promising advances in cancer diagnosis.

Epigenetic alterations are not tumor specific; moreover, there are some genes that are frequently hypermethylated and silenced in different types of tumors. In fact, many studies have analyzed panels of genes to increase sensitivity. ${ }^{83-85}$ 
Thus, it is essential to select accurately the genes to analyze for each type of cancer to improve the sensitivity of the analyses. Some of the most common aberrant methylations affect the $p 16$ tumor suppressor gene and have been found in patients with liver, lung, and breast tumors. ${ }^{82,86,87}$ Other suppressor genes frequently hypermethylated are SEPT9, RASSF1A, GSTP1, and DAPK, among others.

The clinical value of the detection of hypermethylated genes in plasma has been shown in different types of cancer such as breast, ${ }^{84,85}$ colon, ${ }^{53}$ liver, ${ }^{88}$ esophagus, ${ }^{89}$ and urological tumors, ${ }^{90}$ as well as in hematologic diseases. ${ }^{91}$ It has been suggested that the methylated status of cfDNA circulating in plasma might be a tool for prognosis stratification and the prediction of the response to some chemotherapeutics agents, ${ }^{8,9,92}$ disease-free interval, and risk of relapse. ${ }^{53,88,89}$

Hypermethylations have also been detected in cfDNA from other body fluids such as urine..$^{90}$ Specifically, the presence of tumor cfDNA has been reported in $70 \%$ of urine samples, suggesting its utility for the diagnosis and monitoring of patients with urologic tumors such as bladder, prostate and kidney cancers. ${ }^{90}$

\section{Microsatellite alterations}

"Microsatellites" are repeating sequences of one to six nucleotides that are scattered along the genome; their function is unknown. Such sequences serve to identify "loss of heterozygosity" (LOH), which is a frequent alteration of tumor DNA characterized by the loss of an allele when compared with matched normal DNA from the same individual. $\mathrm{LOH}$ indicates the absence of a functional tumor suppressor gene by deletion. In contrast, some tumors have abnormally long or short microsatellites as a result of a defective DNA repair process; this is termed "microsatellite instability" (MSI).

It has been reported that $\mathrm{LOH}$ and MSI can be detected in cfDNA circulating in plasma; however, discrepancies between tumor DNA and plasma cfDNA have been reported. ${ }^{2}$ Although the detection of such alterations in plasma is more probable in advanced stages, some researchers have suggested a potential value for such detection at the diagnosis stage of breast ${ }^{93}$ and ovarian cancers, ${ }^{44}$ which may have an even higher sensitivity than the quantitation of cfDNA. ${ }^{44}$

To increase the sensitivity of this kind of marker, they have been tested in combination with several other plasma markers, such as methylations and prostate-specific antigen in prostate cancer. ${ }^{94}$ In addition, panels of microsatellites are often used to improve sensitivity. ${ }^{95,96}$ For example, in a recent prospective study in breast cancer patients, $\mathrm{LOH}$ was determined by PCR-based microsatellite analysis using a panel of eight polymorphic markers. ${ }^{96}$ The researchers found that $\mathrm{LOH}$ at those markers was significantly correlated with tumor stage, tumor size, lymph node metastasis, positive progesterone, and HER2 status. ${ }^{96}$ Moreover, $\mathrm{LOH}$ at a marker mapping to cyclin D2 correlated with shorter overall survival. Thus, the researchers concluded that the improved detection of LOH on cfDNA provides important information on DNA losses of tumor suppressor genes (TIG1, PTEN, cyclin D2, $R B 1$, and $B R C A 1$ ) in breast cancer. In particular, loss of the cyclin D2 gene may become an important prognostic marker easily detectable in the peripheral blood. ${ }^{96}$

Prior to that interesting study, it was reported that the assessment of microsatellite status in plasma might be a useful predictive tool for prognosis in breast carcinoma, ${ }^{97}$ to monitor the response to surgical treatment; in oral squamous cell carcinoma; ${ }^{95}$ and to biochemotherapy in metastatic melanoma. ${ }^{98}$

\section{Viral DNA}

Viruses are the main etiologic factors of a number of tumors and can be detected in plasma by PCR-based techniques. In fact, the presence of cfDNA of Epstein-Barr virus (EBV) has been demonstrated in nasopharyngeal cancers, Hodgkin's disease, and Burkitt lymphoma; human papillomavirus in cervical tumors; and hepatitis B virus in hepatocellular tumors, certain lymphomas, and gastric cancers. , $^{3,10,12,99-102}$

The presence of EBV sequences in plasma has been the focus of many studies, perhaps due to the high incidence of nasopharyngeal carcinoma in Asian countries. It has been shown that the detection of EBV in plasma is a powerful diagnostic tool and its quantitation might have prognostic value. ${ }^{103}$ In addition, detection of EBV in plasma has also been associated with response to radiotherapy, disease recurrence, and survival. ${ }^{12}$

\section{mitDNA}

Although the study of the genetic and epigenetic alterations of gDNA is the cornerstone of cancer research, the discovery of specific alterations in mitDNA in cancer patients ${ }^{104}$ has opened new routes in the search for clinical tools. The detection of aberrant changes in mitDNA is becoming an important tool for the early diagnosis of cancer, which is in part due to the fact that the analysis of mitDNA has some advantages over that of gDNA. ${ }^{11}$ These advantages can be summarized as follows.

- The mitochondrial genome is shorter and more simply organized than nuclear DNA. These unique properties 
make the screening of a mitochondrial genome much easier and more cost-effective.

- mitDNA's high number of copies, in comparison to nuclear DNA, make it a much more sensitive method.

- mitDNA fragments have been detected in different body fluids from cancer patients at early stages, such as in the blood, ${ }^{104,105}$ saliva, ${ }^{106}$ urine, ${ }^{107}$ and sputum.

The alteration of mitDNA as a response to adaptation changes was first described in the early twentieth century, when it was termed the "Warburg effect." 108 Alterations in mitDNA have been found in the plasma of healthy individuals ${ }^{109}$ and have also be related to tumor development and progression. ${ }^{110}$ The alterations, which are point mutations, deletions, insertions, and quantitative changes, ${ }^{11}$ have been detected in a wide range of tumors, such as breast, colon, liver, head, and neck and lung. ${ }^{111}$ It is important to highlight that the identification of mutations in a concrete region typical to many tumors is referred to as the "D-loop," which may have diagnostic value. ${ }^{104}$

The presence of mitDNA mutations has been reported in plasma and serum samples from patients with hepatocellular, pancreatic, prostatic, colorectal, and esophageal cancers, among others. ${ }^{112-116}$ Moreover, several studies have suggested that quantitation of mitochondrial cfDNA in plasma might serve as a clinical tool, ${ }^{17,118}$ and may even have a higher diagnostic value than gDNA in some cases. ${ }^{118}$ Specifically, Kohler et $\mathrm{al}^{117}$ compared the levels of gDNA and mitDNA in plasma from patients with benign and malignant breast tumors with those from healthy controls. They concluded that both nuclear and mitochondrial cfDNA have potential as biomarkers in breast tumor management; however, the nuclear cfDNA showed greater sensitivity and specificity. Zachariah et $\mathrm{al}^{118}$ conducted a study in 104 women with ovarian cancer, benign tumors, and endometriosis, and compared the levels of gDNA and mitDNA in plasma in these patients. Patients with epithelial ovarian cancer had significantly higher amounts of nuclear and mitochondrial cfDNA than the other women, but the levels of cfDNA in plasma were related to neither pathological parameters nor CA125 levels. In addition, the researchers found that quantitation of mitDNA was a unique way to differentiate between patients with ovarian cancer and endometriosis. ${ }^{118}$

Other studies have used "mitochondrial DNA integrity," which has been defined as the ratio between long and short fragments of mitDNA. ${ }^{119}$ It has been reported that such an index might differentiate between patients with urologic malignancies (renal, prostate, and bladder tumors) and healthy subjects, with a sensitivity of $84 \%$ and a specificity of $97 \% .^{119}$
Finally, it has been reported that some mitDNA polymorphisms are associated with cancer development, thus a genetic analysis of such polymorphisms could help to identify target populations to establish screening programs. ${ }^{11}$

\section{Circulating cell-free RNA (cfRNA) Biology of cfRNA}

The origin of the cfRNA circulating in plasma, its role, and its release mechanisms are yet unknown. The existence of cfRNA in blood was reported many years ago when, in 1987, Wieczorek et $\mathrm{al}^{120}$ found RNA in proteolipid complexes in the serum of cancer patients. ${ }^{121}$ However, the potential clinical value of the detection of cfRNA in plasma did not attract the attention of researchers until 1999, when two parallel studies reported the detection of tyrosinase mRNA in patients with metastatic melanoma ${ }^{122}$ and $\mathrm{mRNA}$ associated with EBV in patients with nasopharyngeal carcinoma. ${ }^{123}$ Many studies have subsequently reported the presence of specific mRNA in plasma from patients with a variety of cancers including colon, ${ }^{124-126}$ breast, ${ }^{127,128}$ prostate, ${ }^{129,130}$ melanoma, ${ }^{122}$ lung, ${ }^{131}$ and thyroid. ${ }^{132}$

It was theorized that the fragility of cfRNA in serum or plasma - due to the fast enzymatic degradation it undergoes, which is increased in cancer patients ${ }^{133}$ - might make its detection difficult. However, it was found that the molecules are more stable than it was presumed, ${ }^{134}$ possibly due to protection by vesicle-like structures.

The origin of cfRNA remains less clear than that of cfDNA. ${ }^{21,24}$ It has been proposed that apoptosis might be involved in the release of cfRNA, and that its association with apoptotic bodies might explain the resistance to nucleases in blood. ${ }^{31}$ However, other hypotheses for the circulation of cfRNA have also been put forward, such as it occurring within lipoprotein complexes ${ }^{24}$ or being in other actively-released particles, such as exosomes. ${ }^{121}$

$\mathrm{Ng}$ et al ${ }^{135}$ examined the particle-associated nature of circulating cfRNA by filtering plasma samples from healthy subjects and cancer patients through material with different pore sizes. They found greater amounts of particle-associated mRNA in cancer patients than in healthy subjects, suggesting that most of the cfRNA not associated with particles had degraded. ${ }^{135}$

\section{Detection and quantitation of cfRNA in plasma and serum}

The use of cfRNA as a biomarker has several advantages including the ease with which plasma or serum samples for testing can be obtained, which makes it feasible for the monitoring of metastatic disease and even for wide 
screenings. However, RNA molecules are fragile, so high sensitivity techniques with simultaneous internal controls are necessary. ${ }^{136}$

One of the most analyzed mRNAs in plasma is that of the human transcriptase reverse telomerase (hTERT), which corresponds to a ribonucleoprotein involved in the repair and lengthening of telomeres in eukaryotic cells. This mRNA is overexpressed in a variety of tumors. ${ }^{124,126,128,129,137-140}$ However, cfRNA is not specific to cancer patients and can also be found in healthy volunteers or in those suffering trauma. ${ }^{46,141}$

In breast cancer patients, using PCR-based techniques, hTERT mRNA has been detected in serum, even in patients with localized disease. ${ }^{128}$ Silva et al ${ }^{127}$ observed that analysis of specific mRNA epithelium (cytokeratin 19) in plasma, in combination with mammaglobin, facilitates the detection of a greater number of positive cases than does analysis of tumor cfDNA (73\% versus [vs] 29\%). Moreover, detection of epithelial mRNA has been found to be related to tumor size and proliferation rate. ${ }^{127}$ In addition, El-Abd et al have suggested the utility of the detection of metastasin mRNA in serum as a survival marker, with high sensitivity $(85 \%)$ and specificity $(100 \%) .{ }^{142}$

In colon cancer patients, an adequate correlation between hTERT levels in plasma and tumor stage has been observed, which has led such a quantitation to be proposed as a tool for screening, monitoring, ${ }^{137}$ and response to treatment. ${ }^{140}$

With respect to lung cancer, Miura et al ${ }^{138}$ analyzed plasma samples from 112 patients and 80 healthy subjects to detect and quantify hTERT and epidermal growth factor receptor (EGFR) mRNAs. They found that the sensitivity and specificity in lung cancer diagnosis were, respectively, $89 \%$ and $73 \%$ for hTERT mRNA, and $71 \%$ and $80 \%$ for EGFR mRNA. Moreover, they found that the number of copies of hTERT mRNA significantly decreased after surgical treatment. ${ }^{138}$ These data led the researchers to suggest that hTERT mRNA, especially when combined with EGFR mRNA, may be an excellent biomarker for pulmonary malignancies to diagnose and assess clinical stage. ${ }^{138}$ In addition, it has been suggested that the detection of heterogeneous nuclear ribonucleoprotein-B1 mRNA and HER2/neu-specific mRNA might have diagnostic value in lung cancer. ${ }^{143}$

In esophagus cancer patients, the detection of squamous cell carcinoma-antigen mRNA (SCC-Ag mRNA) by realtime PCR was shown to be the best predictive factor for recurrence in patients. ${ }^{144}$

In hepatocellular cancer, the detection of hTERT mRNA in serum has been suggested to be of diagnostic value, with a sensitivity of $88 \%$ and a specificity of $70 \% .{ }^{139}$ Moreover, the researchers reported a good correlation between the levels of hTERT mRNA in plasma and clinicopathological parameters, such as degree of differentiation. ${ }^{139}$ However, other studies have shown no correlation with clinicopathological variables such as tumor size. ${ }^{145}$

cfRNA can be detected in other body fluids such as saliva and urine, and satisfactory results have been reported for its detection in these as a marker for the diagnosis of mouth and urological cancers, respectively. ${ }^{136}$

\section{miRNA}

The discovery of miRNA in 1993 was a milestone in cell biology research. From that moment, the number of identified miRNAs steadily increased and, to date, more than 900 human miRNAs have been discovered.

"miRNAs" are small noncoding molecules of 18-22 nucleotides that regulate gene expression, acting at a post-transcriptional level. It is known that a unique miRNA is able to regulate multiple different mRNAs, so that it might potentially alter the function of multiple channels. ${ }^{13}$

miRNAs have been demonstrated to play important roles in control of cell proliferation, cell differentiation, and apoptosis, thus their dysregulation contributes to tumor development. Moreover, it has been demonstrated that miRNAs can function as potential oncogenes or oncosuppressor genes, depending on the cellular context and on the target genes they regulate. ${ }^{146}$ Aberrant expression of miRNAs has been associated with multiple types of cancer including colon, ${ }^{147-150}$ lung, ${ }^{151-154}$ breast, ${ }^{155}$ prostate, ${ }^{156}$ gastric, ${ }^{157}$ and esophagus, ${ }^{158}$ as well as lymphoma. ${ }^{159}$

miRNAs have been detected in the plasma and serum of animals and humans, and in both healthy subjects and cancer patients. The first evidence that miRNAs might serve as serological biomarkers of solid tumors was provided by Mitchell et al ${ }^{156}$ and Chen et al. ${ }^{147}$ miRNAs circulating in plasma have some advantages as clinical markers compared with other forms of cfRNA, since they have a remarkable resistance to endogenous and exogenous ribonuclease activity, extreme $\mathrm{pH}$ conditions, and freeze-thaw cycles, whereas synthetic miRNAs are promptly degraded. ${ }^{160}$

Circulating miRNAs have been found packaged into various membrane-bound vesicles such as exosomes, ${ }^{18}$ microvesicles and apoptotic bodies (reviewed by Zandberga et al), ${ }^{160}$ and also in lipoprotein complexes. ${ }^{141}$ This is probably the main reason for the high resistance of plasma miRNAs, which makes their detection by PCR-based techniques easy. In addition, miRNAs are tissue specific, which allows 
the development of panels to help in the diagnosis of tumors of unknown origin. ${ }^{156,161,162}$ Moreover, they are not only detectable in the bloodstream but also in other body fluids. ${ }^{18,163}$ Thus, the use of miRNAs as serological biomarkers is a very attractive option and research in this field continues to increase.

miR-21, probably the most analyzed miRNA, is often overexpressed in many types of tumors. ${ }^{164}$ Nonetheless, a number of miRNAs have been demonstrated to have potential value as serological biomarkers in cancer, including miR-1, miR-10b, miR-17-92, miR-24, miR-92a, miR-122, miR-141, miR-155, miR-195, miR-221, and miR-375. ${ }^{165}$

The diagnostic value of miRNA panels appears to be superior to that of individual miRNAs. ${ }^{160}$ Specific expression patterns of serum miRNAs have been identified for lung cancer, colorectal cancer, and diabetes, providing evidence that serum miRNAs contain fingerprints for a variety of diseases. ${ }^{147}$

It has been demonstrated that colorectal cancer patients have an miRNA serum profile significantly different to that of healthy subjects. Specifically, 69 miRNAs have been detected in sera from colorectal cancer patients but not in those from healthy subjects. ${ }^{147}$ Moreover, colorectal cancer patients have been found to share a large number of serum miRNAs with lung cancer patients. ${ }^{147} \mathrm{In}$ addition, $\mathrm{Ng}$ et al ${ }^{148}$ analyzed plasma samples from 90 colorectal cancer patients and 50 healthy subjects and found that miR-17-3p and miR-92 were overexpressed in patients, which suggested the potential diagnostic value of such plasma levels, with a sensitivity of $89 \%$ and specificity of $70 \%$. Subsequent studies have supported $\mathrm{Ng}$ et al's findings, including that by Huang et al, ${ }^{149}$ who showed that levels of miR-29a and miR-92a in plasma discriminate colorectal cancer, with $83 \%$ sensitivity and $85 \%$ specificity. In a recent revision, the prediction value of three miRNAs (miR-221, miR-141, and miR-29a) has been highlighted as 3 independent factors of wrong predictions in different clinical stages. ${ }^{166}$

The increased expression of miR-21, miR-106, and miR15 has been observed in breast cancer patients compared with that observed in healthy subjects, in both tissues and serum, and those levels have been found associated with tumor stage and the presence of lymph node metastases. ${ }^{155}$ With respect to lung cancer, Wang et a $1^{152}$ and Liu et $\mathrm{al}^{153}$ observed high levels of miR-21 in the plasma of cancer patients compared with that in healthy individuals. These levels were also associated with TNM stage and the presence of lymph node metastasis. Further, Roth et al ${ }^{154}$ suggested that miR-361-3p and miR625 might have a protective effect on the development of

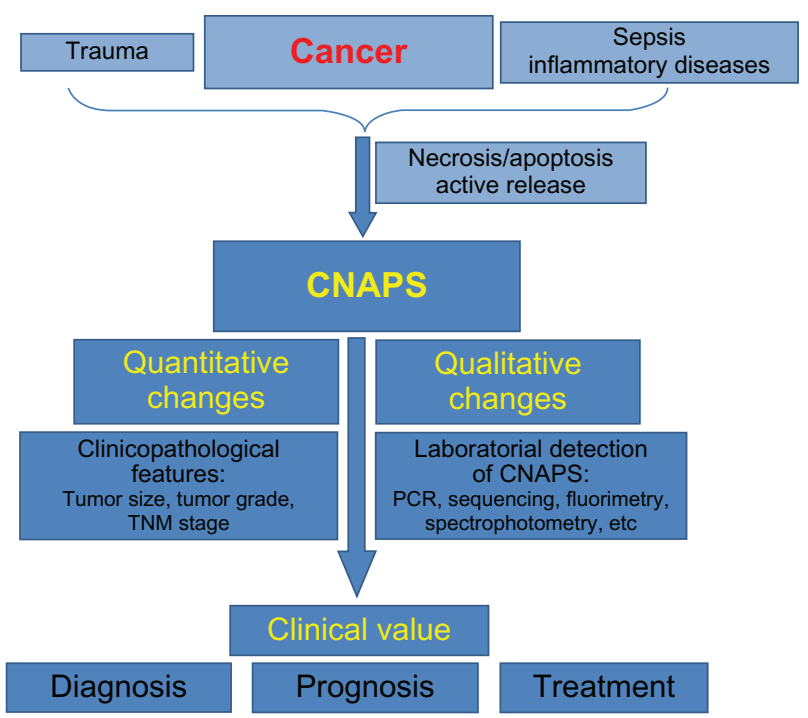

Figure 2 Schematic representation of the outline of the present review. Abbreviations: CNAPS, cell-free nucleic acids in plasma and serum; PCR, polymerase chain reaction; TNM, TNM Classification of Malignant Tumors.

non-small cell lung cancer, while its quantification in serum might have the diagnostic potential to detect that cancer, particularly in smokers.

The most comprehensive search to date for circulating miRNAs with prognostic significance was performed by $\mathrm{Hu}$ et al, ${ }^{151}$ who analyzed a large cohort of 303 patients and found that four plasma miRNAs (miR-486, miR-30d, miR-1, and miR-449) were independent predictors of average survival. In prostate cancer, Mitchell et al ${ }^{156}$ were able to distinguish patients with cancer from healthy individuals by serum levels of miR-141. Finally, Lawrie et al demonstrated that serum levels of miR-21 were associated with the disease-free interval in patients with diffuse B-cell lymphoma. ${ }^{159}$

In future, the search for circulating miRNAs of clinical value is likely to be carried out at the same time as the study of many unknown aspects, such as the role of circulating miRNAs, the cell types that secrete them, and the regulation of this secretion.

\section{Conclusion}

The data reviewed in the present article suggest that the clinical value of cfNAs circulating in plasma is already more than a theoretical idea, since the characterization and the quantitation of such nucleic acids (NAs) have been shown to be complementary tools in the diagnosis, prognosis, and management of cancer patients (Figure 2). However, some important questions remain unanswered, largely because most studies have been underpowered as well as because there has been no adequate standardization of laboratory techniques, 
which complicates the comparison of results from different groups. ${ }^{3,9,10}$ Thus, it appears necessary to drive initiatives directed toward validating and verifying laboratory methods and procedures for required molecular tests before their use in clinical testing. For this, it might be useful to network, as has been demonstrated by successful previous initiatives. ${ }^{167}$ Methods based on sequencing (genome-wide sequencing, exome sequencing, etc) appear to be the definitive tool for making the analysis of cfDNA for cancer monitoring useful, since it allows for personalized assays. ${ }^{26,78}$

However, plasma cfNAs have yet many enigmatic aspects. Elucidation of these might lead us to a revision in the way the pathobiology of cancer is conceived. It is likely that many molecular pathways are involved in the origin of such NAs, since various results point in non-exclusive different directions. It has been postulated that the cfNAs circulating in plasma are not merely biological waste, but that they may be directly involved in the development of metastases, possibly through transfection-like uptake by susceptible cells. ${ }^{168}$ This hypothesis, the "genometastasis theory," is supported by strong evidence - namely, the observation that plasma from cancer patients can transfect and oncogenically transform cultured cells. ${ }^{169,170}$

Regardless, no conclusive explanation of the circulation mechanism of cfNAs yet exists. Several groups have suggested a relationship between the presence of cfNAs in plasma and the presence of exosomes. ${ }^{121,171}$ Thus, it appears feasible that at least part of plasma cfNAs circulates within exosomes. This finding correlates with the idea that plasma cfNAs might have a role in tumor progression, since it has been proven that exosomes are able to transfer their RNA content to cells, and that this RNA can be functional in its new location. ${ }^{18}$ It has even been demonstrated that miRNAs are transferred during immune synapsis and are able to modulate gene expression in recipient cells. ${ }^{172}$ Moreover, cross-talk between tumorderived exosomes and host cells, such as bone marrow progenitor cells, appears undeniable. ${ }^{173}$ Thus, transfer of genetic material from exosomes to cells might be involved in the recruitment and metastatic conversion of host cells. Conversely, it might be possible to exploit this phenomenon for therapeutic purposes and, perhaps, it will be proper to focus the development of clinical tools on the detection and analysis of NAs containing microparticles. Certainly, at this moment, a robust body of research on exosomes and microvesicles exists and increased understanding of such particles in future will shed light on cancer pathobiology and offer promising perspectives on clinical tools.
Thus, although the origin and the circulation mechanism of plasma cfNAs remain unclear, there is strong evidence to suggest that such NAs will become useful biomarkers for the diagnosis and monitoring of cancer disease and that they might be essential to tumor development and progression.

\section{Acknowledgment}

The authors thank Mr Eduard Cervera for his invaluable help in designing Figure 1.

\section{Disclosure}

The authors declare no conflicts of interest in this work.

\section{References}

1. World Health Organization [homepage on the Internet]. Available from: http://www.who.int/features/qa/15/en/. Accessed June 6, 2013.

2. Jacobs EL, Haskell CM. Clinical use of tumor markers in oncology. Curr Probl Cancer. 1991;15(6):299-360.

3. Fleischhacker M, Schmidt B. Circulating nucleic acids (CNAs) and cancer - a survey. Biochim Biophys Acta. 2007;1775(1):181-232.

4. Mandel P, Métais P. Les acides nucléiques du plasma sanguin chez l'homme [The nucleic acids of blood plasma in humans]. Compte Rendu de l'Academie des Sciences. 1948;142:241-243. French.

5. Leon SA, Shapiro B, Sklaroff DM, Yaros MJ. Free DNA in the serum of cancer patients and the effect of therapy. Cancer Res. 1977;37(3): 646-650.

6. Stroun M, Anker P, Maurice P, Lyautey J, Lederrey C, Beljanski M. Neoplastic characteristics of the DNA found in the plasma of cancer patients. Oncology. 1989;46(5):318-322.

7. Sorenson GD, Pribish DM, Valone FH, Memoli VA, Bzik DJ, Yao SL. Soluble normal and mutated DNA sequences from single-copy genes in human blood. Cancer Epidemiol Biomarkers Prev. 1994;3(1):67-71.

8. Vasioukhin V, Anker P, Maurice P, Lyautey J, Lederrey C, Stroun M. Point mutations of the N-ras gene in the blood plasma DNA of patients with myelodysplastic syndrome or acute myelogenous leukaemia. $\mathrm{Br} J$ Haematol. 1994;86(4):774-779.

9. Jung K, Fleischhacker M, Rabien A. Cell-free DNA in the blood as a solid tumor biomarker - a critical appraisal of the literature. Clin Chim Acta. 2010;411(21-22):1611-1624.

10. Schwarzenbach H, Hoon DS, Pantel K. Cell-free nucleic acids as biomarkers in cancer patients. Nat Rev Cancer. 2011;11(6):426-437.

11. Yu M. Somatic mitochondrial DNA mutations in human cancers. Adv Clin Chem. 2012;57:99-138.

12. Tsang JC, Lo YM. Circulating nucleic acids in plasma/serum. Pathology. 2007;39(2):197-207.

13. Giovannetti E, Erozenci A, Smit J, Danesi R, Peters GJ. Molecular mechanisms underlying the role of microRNAs (miRNAs) in anticancer drug resistance and implications for clinical practice. Crit Rev Oncol Hematol. 2012;81(2):103-122.

14. Gahan PB, Anker P, Stroun M. Metabolic DNA as the origin of spontaneously released DNA? Ann N Y Acad Sci. 2008;1137: $7-17$.

15. Holdenrieder S, Stieber P, Bodenmüller H, et al. Circulating nucleosomes in serum. Ann N Y Acad Sci. 2001;945:93-102.

16. Holdenrieder $\mathrm{S}$, Stieber P, Bodenmüller H, et al. Nucleosomes in serum as a marker for cell death. Clin Chem Lab Med. 2001;39(7):596-605.

17. Iguchi H, Kosaka N, Ochiya T. Secretory microRNAs as a versatile communication tool. Commun Integr Biol. 2010;3(5):478-481.

18. Valadi H, Ekström K, Bossios A, Sjöstrand M, Lee JJ, Lötvall JO. Exosome-mediated transfer of mRNAs and microRNAs is a novel mechanism of genetic exchange between cells. Nat Cell Biol. 2007;9(6): 654-659. 
19. García-Olmo DC, García-Olmo D. Biological role of cell-free nucleic acids in cancer: the theory of genometastasis. Crit Rev Oncog. 2013;18(1-2):153-161.

20. Jahr S, Hentze H, Englisch S, et al. DNA fragments in the blood plasma of cancer patients: quantitations and evidence for their origin from apoptotic and necrotic cells. Cancer Res. 2001;61(4):1659-1665.

21. Stroun M, Lyautey J, Lederrey C, Olson-Sand A, Anker P. About the possible origin and mechanism of circulating DNA apoptosis and active DNA release. Clin Chim Acta. 2001;313(1-2):139-142.

22. Li CN, Hsu HL, Wu TL, Tsao KC, Sun CF, Wu JT. Cell-free DNA is released from tumor cells upon cell death: a study of tissue cultures of tumor cell lines. J Clin Lab Anal. 2003;17(4):103-107.

23. Choi JJ, Reich CF, Pisetsky DS. The role of macrophages in the in vitro generation of extracellular DNA from apoptotic and necrotic cells. Immunology. 2005;115(1):55-62.

24. Stroun M, Maurice P, Vasioukhin V, et al. The origin and mechanism of circulating DNA. Ann N Y Acad Sci. 2000;906:161-168.

25. Thijssen MA, Swinkels DW, Ruers TJ, de Kok JB. Difference between free circulating plasma and serum DNA in patients with colorectal liver metastases. Anticancer Res. 2002;22(1A):421-425.

26. Murtaza M, Dawson SJ, Tsui DW, et al. Non-invasive analysis of acquired resistance to cancer therapy by sequencing of plasma DNA. Nature. 2013;497(7447):108-112.

27. Diehl F, Li M, Dressman D, et al. Detection and quantification of mutations in the plasma of patients with colorectal tumors. Proc Natl Acad Sci USA. 2005;102(45):16368-16373.

28. Giacona MB, Ruben GC, Iczkowski KA, Roos TB, Porter DM, Sorenson GD. Cell-free DNA in human blood plasma: length measurements in patients with pancreatic cancer and healthy controls. Pancreas 1998;17(1):89-97.

29. Suzuki N, Kamataki A, Yamaki J, Homma Y. Characterization of circulating DNA in healthy human plasma. Clin Chim Acta. 2008;387(1-2): $55-58$.

30. Holdenrieder S, Stieber P, Chan LY, et al. Cell-free DNA in serum and plasma: comparison of ELISA and quantitative PCR. Clin Chem. 2005;51(8):1544-1546.

31. Hasselmann DO, Rappl G, Tilgen W, Reinhold U. Extracellular tyrosinase mRNA within apoptotic bodies is protected from degradation in human serum. Clin Chem. 2001;47(8):1488-1489.

32. Cherepanova AV, Tamkovich SN, Bryzgunova OE, Vlassov VV, Laktionov PP. Deoxyribonuclease activity and circulating DNA concentration in blood plasma of patients with prostate tumors. Ann NY Acad Sci. 2008;1137:218-221.

33. Frattini M, Gallino G, Signoroni S, et al. Quantitative analysis of plasma DNA in colorectal cancer patients: a novel prognostic tool. Ann NY Acad Sci. 2006;1075:185-190.

34. Sozzi G, Conte D, Leon M, et al. Quantification of free circulating DNA as a diagnostic marker in lung cancer. J Clin Oncol. 2003;21(21): 3902-3908.

35. Szpechcinski A, Chorostowska-Wynimko J, Kupis W, et al. Quantitative analysis of free-circulating DNA in plasma of patients with resectable NSCLC. Expert Opin Biol Ther. 2012;12 Suppl 1:S3-S9.

36. Paci M, Maramotti S, Bellesia E, et al. Circulating plasma DNA as diagnostic biomarker in non-small cell lung cancer. Lung Cancer. 2009;64(1):92-97.

37. Catarino R, Ferreira MM, Rodrigues H, et al. Quantification of free circulating tumor DNA as a diagnostic marker for breast cancer. DNA Cell Biol. 2008;27(8):415-421.

38. Hashad D, Sorour A, Ghazal A, Talaat I. Free circulating tumor DNA as a diagnostic marker for breast cancer. J Clin Lab Anal. 2012;26(6): 467-472.

39. Sai S, Ichikawa D, Tomita H, et al. Quantification of plasma cell-free DNA in patients with gastric cancer. Anticancer Res. 2007;27(4C): 2747-2751.

40. Tomita H, Ichikawa D, Ikoma D, et al. Quantification of circulating plasma DNA fragments as tumor markers in patients with esophageal cancer. Anticancer Res. 2007;27(4C):2737-2741.
41. Shapiro B, Chakrabarty M, Cohn EM, Leon SA. Determination of circulating DNA levels in patients with benign or malignant gastrointestinal disease. Cancer. 1983;51(11):2116-2120.

42. Yoon KA, Park S, Lee SH, Kim JH, Lee JS. Comparison of circulating plasma DNA levels between lung cancer patients and healthy controls. J Mol Diagn. 2009;11(3):182-185.

43. Zhang R, Shao F, Wu X, Ying K. Value of quantitative analysis of circulating cell free DNA as a screening tool for lung cancer: a metaanalysis. Lung Cancer. 2010;69(2):225-231.

44. Chang HW, Lee SM, Goodman SN, et al. Assessment of plasma DNA levels, allelic imbalance, and CA 125 as diagnostic tests for cancer. J Natl Cancer Inst. 2002;94(22):1697-1703.

45. Atamaniuk J, Vidotto C, Tschan H, Bachl N, Stuhlmeier KM, Müller MM. Increased concentrations of cell-free plasma DNA after exhaustive exercise. Clin Chem. 2004;50(9):1668-1670.

46. Laktionov PP, Tamkovich SN, Rykova EY, et al. Extracellular circulating nucleic acids in human plasma in health and disease. Nucleosides Nucleotides Nucleic Acids. 2004;23(6-7):879-883.

47. Lo YM, Rainer TH, Chan LY, Hjelm NM, Cocks RA. Plasma DNA as a prognostic marker in trauma patients. Clin Chem. 2000;46(3): 319-323.

48. Wu TL, Zhang D, Chia JH, Tsao K, Sun CF, Wu JT. Cell-free DNA: measurement in various carcinomas and establishment of normal reference range. Clin Chim Acta. 2002;321(1-2):77-87.

49. Lecomte T, Ceze N, Dorval E, Laurent-Puig P. Circulating free tumor DNA and colorectal cancer. Gastroenterol Clin Biol. 2010;34(12): 662-681.

50. García-Olmo DC, Samos J, Picazo MG, Asensio AI, Toboso I, GarcíaOlmo D. Release of cell-free DNA into the bloodstream leads to high levels of non-tumor plasma DNA during tumor progression in rats. Cancer Lett. 2008;272(1):133-140.

51. García-Olmo DC, Picazo MG, Toboso I, Asensio AI, García-Olmo D. Quantitation of cell-free DNA and RNA in plasma during tumor progression in rats. Mol Cancer. 2013;12:8.

52. Agostini M, Pucciarelli S, Enzo MV, et al. Circulating cell-free DNA: a promising marker of pathologic tumor response in rectal cancer patients receiving preoperative chemoradiotherapy. Ann Surg Oncol. 2011;18(9):2461-2468.

53. Frattini M, Gallino G, Signoroni S, et al. Quantitative and qualitative characterization of plasma DNA identifies primary and recurrent colorectal cancer. Cancer Lett. 2008;263(2):170-181.

54. Holdenrieder S, Stieber P, von Pawel J, et al. Circulating nucleosomes predict the response to chemotherapy in patients with advanced non-small cell lung cancer. Clin Cancer Res. 2004;10(18 Pt 1): 5981-5987.

55. Holdenrieder S, Nagel D, Schalhorn A, et al. Clinical relevance of circulating nucleosomes in cancer. Ann N Y Acad Sci. 2008;1137: 180-189.

56. Gormally E, Caboux E, Vineis P, Hainaut P. Circulating free DNA in plasma or serum as biomarker of carcinogenesis: practical aspects and biological significance. Mutat Res. 2007;635(2-3):105-117.

57. Wang BG, Huang HY, Chen YC, et al. Increased plasma DNA integrity in cancer patients. Cancer Res. 2003;63(14):3966-3968.

58. Umetani N, Kim J, Hiramatsu S, et al. Increased integrity of free circulating DNA in sera of patients with colorectal or periampullary cancer: direct quantitative PCR for ALU repeats. Clin Chem. 2006;52(6): 1062-1069.

59. Umetani N, Giuliano AE, Hiramatsu SH, et al. Prediction of breast tumor progression by integrity of free circulating DNA in serum. J Clin Oncol. 2006;24(26):4270-4276.

60. Chen H, Sun LY, Zheng HQ, Zhang QF, Jin XM. Total serum DNA and DNA integrity: diagnostic value in patients with hepatitis B virus-related hepatocellular carcinoma. Pathology. 2012;44(4): 318-324.

61. Jiang WW, Zahurak M, Goldenberg D, et al. Increased plasma DNA integrity index in head and neck cancer patients. Int $J$ Cancer. 2006;119(11):2673-2676. 
62. Pinzani P, Salvianti F, Zaccara S, et al. Circulating cell-free DNA in plasma of melanoma patients: qualitative and quantitative considerations. Clin Chim Acta. 2011;412(23-24):2141-2145.

63. Gao YJ, He YJ, Yang ZL, et al. Increased integrity of circulating cellfree DNA in plasma of patients with acute leukemia. Clin Chem Lab Med. 2010;48(11):1651-1656.

64. Chan KC, Leung SF, Yeung SW, Chan AT, Lo YM. Persistent aberrations in circulating DNA integrity after radiotherapy are associated with poor prognosis in nasopharyngeal carcinoma patients. Clin Cancer Res. 2008;14(13):4141-4145.

65. Casadio V, Calistri D, Tebaldi M, et al. Urine Cell-Free DNA integrity as a marker for early bladder cancer diagnosis: Preliminary data. Urol Oncol. 2012. Epub Nov 9.

66. Holdenrieder S, Burges A, Reich O, Spelsberg FW, Stieber P. DNA integrity in plasma and serum of patients with malignant and benign diseases. Ann N Y Acad Sci. 2008;1137:162-170.

67. Kopreski MS, Benko FA, Borys DJ, Khan A, McGarrity TJ, Gocke CD. Somatic mutation screening: identification of individuals harboring K-ras mutations with the use of plasma DNA. J Natl Cancer Inst. 2000;92(11):918-923.

68. Sorenson GD. A review of studies on the detection of mutated KRAS2 sequences as tumor markers in plasma/serum of patients with gastrointestinal cancer. Ann N Y Acad Sci. 2000;906:13-16.

69. Garcia JM, Silva JM, Dominguez G, Silva J, Bonilla F. Heterogeneous tumor clones as an explanation of discordance between plasma DNA and tumor DNA alterations. Genes Chromosomes Cancer. 2001;31(3): 300-301.

70. Maire F, Micard S, Hammel P, et al. Differential diagnosis between chronic pancreatitis and pancreatic cancer: value of the detection of KRAS2 mutations in circulating DNA. Br J Cancer. 2002;87(5): 551-554.

71. Castells A, Puig P, Móra J, et al. K-ras mutations in DNA extracted from the plasma of patients with pancreatic carcinoma: diagnostic utility and prognostic significance. J Clin Oncol. 1999;17(2):578-584.

72. Gormally E, Vineis P, Matullo G, et al. TP53 and KRAS2 mutations in plasma DNA of healthy subjects and subsequent cancer occurrence: a prospective study. Cancer Res. 2006;66(13):6871-6876.

73. Chen Z, Feng J, Buzin CH, et al. Analysis of cancer mutation signatures in blood by a novel ultra-sensitive assay: monitoring of therapy or recurrence in non-metastatic breast cancer. PLoS One. 2009;4(9):e7220.

74. Diehl F, Schmidt K, Choti MA, et al. Circulating mutant DNA to assess tumor dynamics. Nat Med. 2008;14(9):985-990.

75. Levy M, Benesova L, Lipska L, et al. Utility of cell-free tumour DNA for post-surgical follow-up of colorectal cancer patients. Anticancer Res. 2012;32(5):1621-1626.

76. Ryan BM, Lefort F, McManus R, et al. A prospective study of circulating mutant KRAS2 in the serum of patients with colorectal neoplasia: strong prognostic indicator in postoperative follow up. Gut. 2003;52(1):101-108.

77. Page K, Hava N, Ward B, et al. Detection of HER2 amplification in circulating free DNA in patients with breast cancer. $\mathrm{Br} J$ Cancer. 2011;104(8):1342-1348.

78. Dawson SJ, Tsui DW, Murtaza M, et al. Analysis of circulating tumor DNA to monitor metastatic breast cancer. NEngl J Med. 2013;368(13): 1199-1209.

79. Gadgeel SM, Cote ML, Schwartz AG, Matherly LH, Wozniak A, Bepler G. Parameters for individualizing systemic therapy in non-small cell lung cancer. Drug Resist Updat. 2010;13(6):196-204.

80. Rosell R, Vergnenegre A, Liu B, et al. Biomarkers in lung oncology. Pulm Pharmacol Ther. 2010;23(6):508-514.

81. Mack PC, Holland WS, Burich RA, et al. EGFR mutations detected in plasma are associated with patient outcomes in erlotinib plus docetaxel-treated non-small cell lung cancer. J Thorac Oncol. 2009;4(12):1466-1472.

82. Esteller M, Sanchez-Cespedes M, Rosell R, Sidransky D, Baylin SB, Herman JG. Detection of aberrant promoter hypermethylation of tumor suppressor genes in serum DNA from non-small cell lung cancer patients. Cancer Res. 1999;59(1):67-70.
83. Lo YM, Wong IH, Zhang J, Tein MS, Ng MH, Hjelm NM. Quantitative analysis of aberrant p16 methylation using real-time quantitative methylation-specific polymerase chain reaction. Cancer Res. 1999;59(16):3899-3903.

84. Casciano I, Vinci AD, Banelli B, et al. Circulating tumor nucleic acids: perspective in breast Cancer. Breast care (Basel). 2010;5(2): 75-80.

85. Radpour R, Barekati Z, Kohler C, et al. Hypermethylation of tumor suppressor genes involved in critical regulatory pathways for developing a blood-based test in breast cancer. PLoS One. 2011; 6(1):e16080.

86. Wong IH, Lo YM, Zhang J, et al. Detection of aberrant p16 methylation in the plasma and serum of liver cancer patients. Cancer Res. 1999;59(1):71-73.

87. Silva JM, Dominguez G, Villanueva MJ, et al. Aberrant DNA methylation of the p16INK4a gene in plasma DNA of breast cancer patients. Br J Cancer. 1999;80(8):1262-1264.

88. Tsutsui M, Iizuka N, Moribe T, et al. Methylated cyclin D2 gene circulating in the blood as a prognosis predictor of hepatocellular carcinoma. Clin Chim Acta. 2010;411(7-8):516-520.

89. Ling ZQ, Zhao Q, Zhou SL, Mao WM. MSH2 promoter hypermethylation in circulating tumor DNA is a valuable predictor of disease-free survival for patients with esophageal squamous cell carcinoma. Eur J Surg Oncol. 2012;38(4):326-332.

90. Goessl C, Müller M, Straub B, Miller K. DNA alterations in body fluids as molecular tumor markers for urological malignancies. Eur Urol. 2002;41(6):668-676.

91. Iriyama $\mathrm{C}$, Tomita $\mathrm{A}, \mathrm{Hoshino} \mathrm{H}$, et al. Using peripheral blood circulating DNAs to detect $\mathrm{CpG}$ global methylation status and genetic mutations in patients with myelodysplastic syndrome. Biochem Biophys Res Commun. 2012;419(4):662-669.

92. Fiegl H, Millinger S, Mueller-Holzner E, et al. Circulating tumorspecific DNA: a marker for monitoring efficacy of adjuvant therapy in cancer patients. Cancer Res. 2005;65(4):1141-1145.

93. Schwarzenbach H, Müller V, Stahmann N, Pantel K. Detection and characterization of circulating microsatellite-DNA in blood of patients with breast cancer. Ann NY Acad Sci. 2004;1022:25-32.

94. Sunami E, Shinozaki M, Higano CS, et al. Multimarker circulating DNA assay for assessing blood of prostate cancer patients. Clin Chem. 2009;55(3):559-567.

95. Hamana K, Uzawa K, Ogawara K, et al. Monitoring of circulating tumour-associated DNA as a prognostic tool for oral squamous cell carcinoma. Br J Cancer. 2005;92(12):2181-2184.

96. Schwarzenbach H, Müller V, Milde-Langosch K, Steinbach B, Pantel K. Evaluation of cell-free tumour DNA and RNA in patients with breast cancer and benign breast disease. Mol Biosyst. 2011;7(10): 2848-2854.

97. Garcia JM, Garcia V, Silva J, et al. Extracellular tumor DNA in plasma and overall survival in breast cancer patients. Genes Chromosomes Cancer. 2006;45(7):692-701.

98. Taback B, O'Day SJ, Boasberg PD, et al. Circulating DNA microsatellites: molecular determinants of response to biochemotherapy in patients with metastatic melanoma. $J$ Natl Cancer Inst. 2004;96(2): $152-156$.

99. Chan KC, Lo YM. Circulating tumour-derived nucleic acids in cancer patients: potential applications as tumour markers. Br J Cancer. 2007;96(5):681-685.

100. Jones K, Nourse JP, Keane C, et al. Tumor-specific but not nonspecific cell-free circulating DNA can be used to monitor disease response in lymphoma. Am J Hematol. 2012;87(3):258-265.

101. Lei KI, Chan LY, Chan WY, Johnson PJ, Lo YM. Quantitative analysis of circulating cell-free Epstein-Barr virus (EBV) DNA levels in patients with EBV-associated lymphoid malignancies. $\mathrm{Br} J$ Haematol. 2000;111(1):239-246.

102. Lo YM, Chan WY, Ng EK, et al. Circulating Epstein-Barr virus DNA in the serum of patients with gastric carcinoma. Clin Cancer Res. 2001;7(7):1856-1859. 
103. Lo YM. Prognostic implication of pretreatment plasma/serum concentration of Epstein-Barr virus DNA in nasopharyngeal carcinoma. Biomed Pharmacother. 2001;55(7):362-365.

104. Fliss MS, Usadel H, Caballero OL, et al. Facile detection of mitochondrial DNA mutations in tumors and bodily fluids. Science. 2000;287(5460):2017-2019.

105. Xia P, An HX, Dang CX, et al. Decreased mitochondrial DNA content in blood samples of patients with stage I breast cancer. BMC Cancer. 2009;9:454.

106. Mithani SK, Smith IM, Zhou S, et al. Mitochondrial resequencing arrays detect tumor-specific mutations in salivary rinses of patients with head and neck cancer. Clin Cancer Res. 2007;13(24): 7335-7340.

107. Jerónimo C, Nomoto S, Caballero OL, et al. Mitochondrial mutations in early stage prostate cancer and bodily fluids. Oncogene. 2001;20(37):5195-5198.

108. Warburg O, Wind F, Negelein E. The metabolism of tumors in the body. J Gen Physiol. 1927;8(6):519-530.

109. Chiu RW, Chan LY, Lam NY, et al. Quantitative analysis of circulating mitochondrial DNA in plasma. Clin Chem. 2003;49(5):719-726.

110. Lee HC, Chang CM, Chi CW. Somatic mutations of mitochondrial DNA in aging and cancer progression. Ageing Res Rev. 2010;9 Suppl 1: S47-S58.

111. Copeland WC, Wachsman JT, Johnson FM, Penta JS. Mitochondrial DNA alterations in cancer. Cancer Invest. 2002;20(4):557-569.

112. Okochi O, Hibi K, Uemura T, et al. Detection of mitochondrial DNA alterations in the serum of hepatocellular carcinoma patients. Clin Cancer Res. 2002;8(9):2875-2878.

113. Kassauei K, Habbe N, Mullendore ME, Karikari CA, Maitra A, Feldmann G. Mitochondrial DNA mutations in pancreatic cancer. Int J Gastrointest Cancer. 2006;37(2-3):57-64.

114. Mehra N, Penning M, Maas J, van Daal N, Giles RH, Voest EE. Circulating mitochondrial nucleic acids have prognostic value for survival in patients with advanced prostate cancer. Clin Cancer Res 2007;13(2 Pt 1):421-426.

115. Hibi K, Nakayama H, Yamazaki T, et al. Mitochondrial DNA alteration in esophageal cancer. Int J Cancer. 2001;92(3):319-321.

116. Hibi K, Nakayama H, Yamazaki T, et al. Detection of mitochondrial DNA alterations in primary tumors and corresponding serum of colorectal cancer patients. Int J Cancer. 2001;94(3):429-431.

117. Kohler C, Radpour R, Barekati Z, et al. Levels of plasma circulating cell free nuclear and mitochondrial DNA as potential biomarkers for breast tumors. Mol Cancer. 2009;8:105.

118. Zachariah RR, Schmid S, Buerki N, Radpour R, Holzgreve W, Zhong X. Levels of circulating cell-free nuclear and mitochondrial DNA in benign and malignant ovarian tumors. Obstet Gynecol. 2008;112(4):843-850.

119. Ellinger J, Müller DC, Müller SC, et al. Circulating mitochondrial DNA in serum: a universal diagnostic biomarker for patients with urological malignancies. Urol Oncol. 2012;30(4):509-515.

120. Wieczorek AJ, Sitaramam V, Machleidt W, Rhyner K, Perruchoud AP, Block LH. Diagnostic and prognostic value of RNA-proteolipid in sera of patients with malignant disorders following therapy: first clinical evaluation of a novel tumor marker. Cancer Res. 1987;47(23): 6407-6412.

121. Lässer C, Alikhani VS, Ekström K, et al. Human saliva, plasma and breast milk exosomes contain RNA: uptake by macrophages. J Transl Med. 2011;9:9.

122. Kopreski MS, Benko FA, Kwak LW, Gocke CD. Detection of tumor messenger RNA in the serum of patients with malignant melanoma Clin Cancer Res. 1999;5(8):1961-1965.

123. Lo KW, Lo YM, Leung SF, et al. Analysis of cell-free Epstein-Barr virus associated RNA in the plasma of patients with nasopharyngeal carcinoma. Clin Chem. 1999;45(8 Pt 1):1292-1294.

124. Dasí F, Lledó S, García-Granero E, et al. Real-time quantification in plasma of human telomerase reverse transcriptase (hTERT) mRNA: a simple blood test to monitor disease in cancer patients. Lab Invest 2001;81(5):767-769.
125. Silva JM, Rodriguez R, Garcia JM, et al. Detection of epithelial tumour RNA in the plasma of colon cancer patients is associated with advanced stages and circulating tumour cells. Gut. 2002;50(4):530-534.

126. Lledó SM, Garcia-Granero E, Dasí F, et al. Real time quantification in plasma of human telomerase reverse transcriptase (hTERT) mRNA in patients with colorectal cancer. Colorectal Dis. 2004;6(4):236-242.

127. Silva JM, Dominguez G, Silva J, et al. Detection of epithelial messenger RNA in the plasma of breast cancer patients is associated with poor prognosis tumor characteristics. Clin Cancer Res. 2001;7(9): 2821-2825.

128. Chen XQ, Bonnefoi H, Pelte MF, et al. Telomerase RNA as a detection marker in the serum of breast cancer patients. Clin Cancer Res. 2000;6(10):3823-3826.

129. Dasí F, Martínez-Rodes P, March JA, et al. Real-time quantification of human telomerase reverse transcriptase mRNA in the plasma of patients with prostate cancer. Ann NY Acad Sci. 2006;1075:204-210.

130. March-Villalba JA, Martínez-Jabaloyas JM, Herrero MJ, Santamaría J, Aliño SF, Dasí F. Plasma hTERT mRNA discriminates between clinically localized and locally advanced disease and is a predictor of recurrence in prostate cancer patients. Expert Opin Biol Ther. 2012; 12 Suppl 1:S69-S77.

131. Kopreski MS, Benko FA, Gocke CD. Circulating RNA as a tumor marker: detection of 5T4 mRNA in breast and lung cancer patient serum. Ann N Y Acad Sci. 2001;945:172-178.

132. Chinnappa P, Taguba L, Arciaga R, et al. Detection of thyrotropinreceptor messenger ribonucleic acid (mRNA) and thyroglobulin mRNA transcripts in peripheral blood of patients with thyroid disease: sensitive and specific markers for thyroid cancer. J Clin Endocrinol Metab. 2004;89(8):3705-3709.

133. Reddi KK, Holland JF. Elevated serum ribonuclease in patients with pancreatic cancer. Proc Natl Acad Sci U S A. 1976;73(7):2308-2310.

134. Tsui NB, Ng EK, Lo YM. Stability of endogenous and added RNA in blood specimens, serum, and plasma. Clin Chem. 2002;48(10):1647-1653.

135. Ng EK, Tsui NB, Lam NY, et al. Presence of filterable and nonfilterable mRNA in the plasma of cancer patients and healthy individuals. Clin Chem. 2002;48(8):1212-1217.

136. Tzimagiorgis G, Michailidou EZ, Kritis A, Markopoulos AK, Kouidou S. Recovering circulating extracellular or cell-free RNA from bodily fluids. Cancer Epidemiol. 2011;35(6):580-589.

137. Terrin L, Rampazzo E, Pucciarelli S, et al. Relationship between tumor and plasma levels of hTERT mRNA in patients with colorectal cancer: implications for monitoring of neoplastic disease. Clin Cancer Res. 2008;14(22):7444-7451

138. Miura N, Nakamura H, Sato R, et al. Clinical usefulness of serum telomerase reverse transcriptase (hTERT) mRNA and epidermal growth factor receptor (EGFR) mRNA as a novel tumor marker for lung cancer. Cancer Sci. 2006;97(12):1366-1373.

139. Miura N, Maruyama S, Oyama K, et al. Development of a novel assay to quantify serum human telomerase reverse transcriptase messenger RNA and its significance as a tumor marker for hepatocellular carcinoma. Oncology. 2007;72 Suppl 1:45-51.

140. Pucciarelli S, Rampazzo E, Briarava M, et al. Telomere-specific reverse transcriptase (hTERT) and cell-free RNA in plasma as predictors of pathologic tumor response in rectal cancer patients receiving neoadjuvant chemoradiotherapy. Ann Surg Oncol. 2012;19(9):3089-3096.

141. El-Hefnawy T, Raja S, Kelly L, et al. Characterization of amplifiable, circulating RNA in plasma and its potential as a tool for cancer diagnostics. Clin Chem. 2004;50(3):564-573.

142. El-Abd E, El-Tahan R, Fahmy L, et al. Serum metastasin mRNA is an important survival predictor in breast cancer. Br J Biomed Sci. 2008;65(2):90-94

143. Fleischhacker M, Beinert T, Ermitsch M, et al. Detection of amplifiable messenger RNA in the serum of patients with lung cancer. Ann NY Acad Sci. 2001;945:179-188.

144. Honma H, Kanda T, Ito H, et al. Squamous cell carcinoma-antigen messenger RNA level in peripheral blood predicts recurrence after resection in patients with esophageal squamous cell carcinoma. Surgery. 2006;139(5):678-685. 
145. Dong ZZ, Yao DF, Yao M, et al. Clinical impact of plasma TGF-beta1 and circulating TGF-beta1 mRNA in diagnosis of hepatocellular carcinoma. Hepatobiliary Pancreat Dis Int. 2008;7(3):288-295.

146. Iorio MV, Croce CM. MicroRNAs in cancer: small molecules with a huge impact. J Clin Oncol. 2009;27(34):5848-5856.

147. Chen X, Ba Y, Ma L, et al. Characterization of microRNAs in serum: a novel class of biomarkers for diagnosis of cancer and other diseases. Cell Res. 2008;18(10):997-1006.

148. Ng EK, Chong WW, Jin H, et al. Differential expression of microRNAs in plasma of patients with colorectal cancer: a potential marker for colorectal cancer screening. Gut. 2009;58(10):1375-1381.

149. Huang Z, Huang D, Ni S, Peng Z, Sheng W, Du X. Plasma microRNAs are promising novel biomarkers for early detection of colorectal cancer. Int J Cancer. 2010;127(1):118-126.

150. Kosaka N, Iguchi H, Ochiya T. Circulating microRNA in body fluid: a new potential biomarker for cancer diagnosis and prognosis. Cancer Sci. 2010;101(10):2087-2092.

151. Hu Z, Chen X, Zhao Y, et al. Serum microRNA signatures identified in a genome-wide serum microRNA expression profiling predict survival of non-small-cell lung cancer. J Clin Oncol. 2010;28(10):1721-1726.

152. Wang ZX, Bian HB, Wang JR, Cheng ZX, Wang KM, De W. Prognostic significance of serum miRNA-21 expression in human non-small cell lung cancer. J Surg Oncol. 2011;104(7):847-851.

153. Liu XG, Zhu WY, Huang YY, et al. High expression of serum miR-21 and tumor miR-200c associated with poor prognosis in patients with lung cancer. Med Oncol. 2012;29(2):618-626.

154. Roth C, Stückrath I, Pantel K, Izbicki JR, Tachezy M, Schwarzenbach H. Low levels of cell-free circulating miR-361-3p and miR-625* as bloodbased markers for discriminating malignant from benign lung tumors. PLoS One. 2012;7(6):e38248.

155. Wang F, Zheng Z, Guo J, Ding X. Correlation and quantitation of microRNA aberrant expression in tissues and sera from patients with breast tumor. Gynecol Oncol. 2010;119(3):586-593.

156. Mitchell PS, Parkin RK, Kroh EM, et al. Circulating microRNAs as stable blood-based markers for cancer detection. Proc Natl Acad Sci US A. 2008;105(30):10513-10518.

157. Bandres E, Bitarte N, Arias F, et al. microRNA-451 regulates macrophage migration inhibitory factor production and proliferation of gastrointestinal cancer cells. Clin Cancer Res. 2009;15(7):2281-2290.

158. Yang H, Gu J, Wang KK, et al. MicroRNA expression signatures in Barrett's esophagus and esophageal adenocarcinoma. Clin Cancer Res. 2009;15(18):5744-5752.

159. Lawrie CH, Gal S, Dunlop HM, et al. Detection of elevated levels of tumour-associated microRNAs in serum of patients with diffuse large B-cell lymphoma. Br J Haematol. 2008;141(5):672-675.
160. Zandberga E, Kozirovskis V, Ābols A, Andrējeva D, Purkalne G, Linē A. Cell-free microRNAs as diagnostic, prognostic, and predictive biomarkers for lung cancer. Genes Chromosomes Cancer. 2013;52(4):356-369.

161. Lu J, Getz G, Miska EA, et al. MicroRNA expression profiles classify human cancers. Nature. 2005;435(7043):834-838.

162. Rosenfeld N, Aharonov R, Meiri E, et al. MicroRNAs accurately identify cancer tissue origin. Nat Biotechnol. 2008;26(4):462-469.

163. Weber JA, Baxter DH, Zhang S, et al. The microRNA spectrum in 12 body fluids. Clin Chem. 2010;56(11):1733-1741.

164. Xie L, Qian X, Liu B. MicroRNAs: novel biomarkers for gastrointestinal carcinomas. Mol Cell Biochem. 2010;341(1-2):291-299.

165. Mo MH, Chen L, Fu Y, Wang W, Fu SW. Cell-free Circulating miRNA Biomarkers in Cancer. J Cancer. 2012;3:432-448.

166. Tokarz P, Blasiak J. The role of microRNA in metastatic colorectal cancer and its significance in cancer prognosis and treatment. Acta Biochim Pol. 2012;59(4):467-474.

167. Mattocks CJ, Morris MA, Matthijs G, et al. A standardized framework for the validation and verification of clinical molecular genetic tests. Eur J Hum Genet. 2010;18(12):1276-1288.

168. García-Olmo D, García-Olmo DC, Ontañón J, Martinez E, Vallejo M. Tumor DNA circulating in the plasma might play a role in metastasis. The hypothesis of the genometastasis. Histol Histopathol. 1999;14(4): 1159-1164.

169. García-Olmo DC, Domínguez C, García-Arranz M, et al. Cell-free nucleic acids circulating in the plasma of colorectal cancer patients induce the oncogenic transformation of susceptible cultured cells. Cancer Res. 2010;70(2):560-567.

170. García-Olmo D, García-Olmo DC, Domínguez-Berzosa C, Guadalajara H, Vega L, García-Arranz M. Oncogenic transformation induced by cell-free nucleic acids circulating in plasma (genometastasis) remains after the surgical resection of the primary tumor: a pilot study. Expert Opin Biol Ther. 2012;12 Suppl 1:S61-S68.

171. Silva J, Garcia V, Rodriguez M, et al. Analysis of exosome release and its prognostic value in human colorectal cancer. Genes Chromosomes Cancer. 2012;51(4):409-418.

172. Mittelbrunn M, Gutiérrez-Vázquez C, Villarroya-Beltri C, et al. Unidirectional transfer of microRNA-loaded exosomes from $\mathrm{T}$ cells to antigen-presenting cells. Nat Commun. 2011;2:282.

173. Peinado H, Alečković M, Lavotshkin S, et al. Melanoma exosomes educate bone marrow progenitor cells toward a pro-metastatic phenotype through MET. Nat Med. 2012;18(6):883-891.
OncoTargets and Therapy

\section{Publish your work in this journal}

OncoTargets and Therapy is an international, peer-reviewed, open access journal focusing on the pathological basis of all cancers, potential targets for therapy and treatment protocols employed to improve the management of cancer patients. The journal also focuses on the impact of management programs and new therapeutic agents and protocols on

\section{Dovepress}

patient perspectives such as quality of life, adherence and satisfaction The manuscript management system is completely online and includes a very quick and fair peer-review system, which is all easy to use. Visit http://www.dovepress.com/testimonials.php to read real quotes from published authors. 